\title{
The Degrees of Practicing Intensive English Language Reading Comprehension Skills by Eleventh Grade Students in the Directorate of Education in Irbid Kasbah District from Their Points of View
}

\author{
Helah Aref Harafsheh ${ }^{1, *}$, Abdallah Ahmad Baniabdelrahman², Fawwaz M. Al-Abed Al-Haq ${ }^{3}$ \\ ${ }^{1}$ JTA (Jordanian Translator Association), Yarmouk University, Irbid, Jordan \\ ${ }^{2}$ Department of Curriculum and Instruction, Faculty of Education, Yarmouk University, Irbid, Jordan \\ ${ }^{3}$ Department of English Language and Literature, Faculty of Arts, Yarmouk University, Irbid, Jordan
}

Received September 24, 2020; Revised November 23, 2020; Accepted December 6, 2020

\begin{abstract}
Cite This Paper in the following Citation Styles
(a): [1] Helah Aref Harafsheh, Abdallah Ahmad Baniabdelrahman, Fawwaz M. Al-Abed Al-Haq, "The Degrees of Practicing Intensive English Language Reading Comprehension Skills by Eleventh Grade Students in the Directorate of Education in Irbid Kasbah District from Their Points of View, "Universal Journal of Educational Research, Vol. 8, No. 12B, pp. 8034-8044, 2020. DOI: 10.13189/ujer.2020.082604.
\end{abstract}

(b): Helah Aref Harafsheh, Abdallah Ahmad Baniabdelrahman, Fawwaz M. Al-Abed Al-Haq (2020). The Degrees of Practicing Intensive English Language Reading Comprehension Skills by Eleventh Grade Students in the Directorate of Education in Irbid Kasbah District from Their Points of View. Universal Journal of Educational Research, 8(12B), 8034-8044. DOI: 10.13189/ujer.2020.082604.

Copyright $\odot 2020$ by authors, all rights reserved. Authors agree that this article remains permanently open access under the terms of the Creative Commons Attribution License 4.0 International License

\begin{abstract}
This study aimed at identifying the degrees of practicing the Intensive Reading comprehension skills by students in the Directorate of Education in Irbid Kasbah District from their points of view. To achieve the aims of the study, a descriptive-analytical approach was used, and a questionnaire was prepared to collect data after verifying their validity and stability. The participants of the study included 101 students in the eleventh grade in the academic year $(2020 / 2021)$. The results of the study showed that the use of Intensive English Reading skills by the students was moderate from their points of view. Furthermore, the results showed statistically significant differences in the use of Intensive English Reading skills by students due to the gender variable. In the light of the results, the researchers recommended some recommendations, such as the teachers should maintain the progress of the students in Intensive Reading and encourage them to read English texts more and balance the teaching-learning activities to achieve the students' competencies in mastering four skills of the language.
\end{abstract}

Keywords Degrees of Practice, Eleventh-Grade Students, Intensive Reading Comprehension Skills, Points of View

\section{Introduction}

Reading receives a particular focus in many second and foreign language (ESL/EFL) teaching situations (Richard $\&$ Renandya, 2002). However, many students are not used to reading English material because reading in the context of a foreign language is not easy. This problem was one of the reasons students were reluctant to read (Cahyono \& Widiawati, 2006). Reading comprehension involves understanding and interpreting what is read using students' background experiences. As such, the success or failure of students in English largely depends on their reading comprehension skills (Murphy, 2015).

Alzu'bi (2014) claimed that many students in Jordan gain little information from reading English material. They read without any particular strategies for remembering new words, getting the main ideas, getting the meaning by the context, recognizing and applying grammar, or reading at the discourse level. Therefore, 
teachers need to explore reading comprehension strategies in improving language reading proficiency, word knowledge, and grammar, to help students comprehend what they are reading.

The inadequacy of English language reading skills has been reported as one of the problems of English language education in Jordan (Al-Khatib, 2008). Therefore, schools and teachers sense that they are left on their own, leaving them lost for what approaches they have to consider for the twenty-first century considerable reading skills needed to their students (Alhabahba, Pandian \& Mahfoodh, 2016). Based on Asmawati (2015), the students have low skills in comprehending English texts and have low participation in the teaching and learning process because they are difficult to understand and catch the information in the reading text when the students do the exercise in the text; they have difficulty answering the questions because they do not know the content of the text.

Reading is a complex activity, and one of the strategies has been used in developing reading skills, known as intensive reading. It is believed that this strategy can be beneficial, in one way or another, to improve students' reading comprehension ability (Popescu, 2012). Intensive reading is a divided vocabulary and sentence structure analysis that dominates the ELT cycle (Pollard, Dorodo, Gonzalez, Simmons, Cooke, Taylor, Davis, \& Simmons, 2011; Day \& Bamford, 2004). So, intensive reading is a powerful tool for improving reading comprehension.

Many definitions have emerged concerning the reading skill because of its importance among the other skills. Therefore, several specialists confirm the importance of reading. Al-Qudah, Al-Khataybeh \& Mohaidat (2002) state that of all language skills, reading is essential for independent learning. Through reading, students can access further knowledge both about the language and about other subjects. Al-Drees (2008, p. 18) confirms, "by reading a lot; the readers can advance their English background knowledge and broaden the vision, inspire their thought, build the values, train the creative performance and develop their intelligence."

Furthermore, Mayer (2003, p. 26) points out that reading comprehension is a "technique for improving students' success in extracting useful knowledge from the text". Another definition is "reading comprehension is a visual and cognitive process to extract meaning from writing by understanding the written text processing information and relating it to existing experience" (Millrood, 2011, p. 117).

Reading comprehension is one of the essential components of reading to master. It requires students to move beyond decoding individual vocabulary and statements to constructing a solid understanding of the entire passage. Comprehension is a complex process that requires an active interaction between the students' background knowledge of the context, the purpose of the reading material, the level of vocabulary and language used by the authors to gain meaning of a text (Fountas \& Pinnell, 2001). The process is complicated because it requires students to engage in considerable cognitive activities, processes, and skills. These skills involve fluently decoding words, understanding the language syntax, making inferences, using background knowledge, and managing working memory as needed (Kendeou, McMaster, \& Christ, 2016).

The researchers conclude from the above definitions that reading means getting meaning encoded by the writer from the text. Furthermore, reading comprehension is an interactive technique in which the reader uses different skills to interact with the text and employ his/her experience and previous knowledge to get the intended meaning. Also, it is a process that involves the interaction of the reader, the text, and the context; it is the ability to understand what is being read.

Students need English reading comprehension skills to be successful in both academic and personal life. In students' academic lives, reading comprehension is the basis for understanding the English subject content. Reading is a vital skill because it provides students with the knowledge, various skills, values, good manners, and pleasure. As the researchers aim to identify the degrees of practicing the Intensive Reading comprehension skills by English teachers; it is important not to neglect the importance of practicing reading skills as a teaching tool. Reading is considered the mother of all skills, and so it is a necessary tool of learning and one of the essential skills in everyday life (Ali, 2010).

The importance of reading comprehension increases significantly in English subjects as students go ahead through grades. In particular, students need reading comprehension skills to accomplish educational expectations at school. For example, students are expected to understand what they are reading to research topics on different topics. Also, to understand what they are reading allows students to locate information quickly, exclude non-relevant information to the topic, and identify the critical information to focus on (Wong, 2011). Academic success also requires students to understand, analyze, and apply the information they gathered through reading. Also, students need reading comprehension skills to understand and perform their assignments. However, without having reading comprehension skills, students cannot accomplish all of that work (Clarke, Truelove, Hulme, \& Snowling, 2013).

McDonough and Shaw (1993) argue that reading is the most fruitful foreign language skill to teach, especially where students have to read English material for their specialist subjects but may never speak the language. Furthermore, Rabel (2005) adds that reading develops a being's creativity. Unlike movies, where everything is determined by the producer, writer, and director, and books allow students to create in their minds how a particular character looks like or imagine how a scene 
plays out. Reading a book allows a student to exercise and cultivate her/his creative thinking skills.

English reading comprehension is also an essential skill that individuals need to be successful in their personal lives. For instance, individuals need English reading comprehension skills to have and maintain a good job and successfully engage in different activities. Individuals who cannot understand the English language might find a job, but the pay rate will be much less than proficient readers (Hoeh, 2015).

Hamdan (1991) emphasizes that reading comprehension in English as a foreign language is important because it trains students to obtain information quickly and provides primary language forms: rhythm, spelling, pronunciation. It is worth noting that reading expands students' knowledge with more vocabulary, ideas, cultural content, language functions, and expressions. Reading also improves students' English language proficiency because it provides realistic situations and an additional communication tool for listening and speaking. Besides, it provides access to literature, magazines, and civilization, and also enhances the basic knowledge they have acquired.

\subsection{Intensive Reading}

Intensive reading refers to the method of reading through every word of a text from beginning to end very thoroughly and deeply. It is the way of reading short texts thoroughly and with clear goals (Koay, 2015). Wright \& Brown (2006) explain that intensive reading calls attention to grammatical forms, discourse markers, and other surface structure details to understand literal meaning, implications, rhetorical relationships, and the like.

(MacLeod, 2013) stated that Intensive Reading is called narrow reading because students have different options to understand the meaning of the text by providing the opportunity to repeat reading several texts on the same topic, content and grammatical structures.

The researchers conclude from the above definitions that Intensive reading is a teaching skill, aims to develop the students' ability to understand detailed information; it is the way of reading short texts thoroughly and with clear goals.

Vaughn (2012) claimed that Intensive Reading materials are brief texts of no more than 500 words in length. They are also usually chosen by the teacher according to the students' level; to achieve the desired outcomes that the teacher wants to cover in the textbook.

Also, Intensive Reading activities may include identifying words linking one idea to another, looking at ideas versus details, understanding what is implicit versus what is being said, reaching conclusions, looking at the order of information and how it affects the message, and identifying words that indicate change from section to another (Baran, 2003).

The intensive reading assessment takes reading quizzes and tests forms. Intensive reading activities include skimming a text to get specific information to answer true or false phrases or filling in gaps in the summary, scanning the text to match titles to paragraphs, scanning mixed paragraphs and then carefully reading them to put them in the correct order. Instead, teachers should spend most of the time training students to understand what they are reading (Alderson, 2015). Teacher in intensive reading chooses suitable text, chooses tasks and activities to develop skills, gives direction before, during and after reading, encourages students through prompts, without giving answers, and prepares students to work independently (Yang, 2012).

Intensive reading has some advantages and challenges. The advantages are: it provides a base to study structure, vocabulary, and idioms, it provides a base for students to develop greater control of language, and it provides a check on the degree of comprehension for individual students (MacLeod, 2013).

On the one hand, intensive reading faces some challenges: Textbook-based learning restricts the creative development of students 'reading abilities and restricts students' learning curiosity. It is difficult to meet the learning needs of students for all-round development in listening, speaking, reading, writing and language application. Intensive traditional reading classes focus on the teacher while students are passive most of the time. The easiest way for teachers is to give lectures while students listen and take notes. This means that the teacher usually does most of the speech, while students listen and do the exercises. Then the teachers provide them with standard answers and explanations accordingly. (Arnawati, 2012).

\subsection{Intensive Reading Comprehension Skills}

Reading comprehension involves a variety of skills. Several specialists prepared lists for these skills. The main skills and sub-skills utilized in reading are predictions, skimming, which means reading quickly to get the main idea or gist, also scanning, which means reading quickly for a specific piece of information. Other essential reading skills are distinguishing between factual and non-factual information, important and less important items, relevant and irrelevant information, explicit and implicit information ideas and examples, and opinions. Also, drawing inferences and conclusions, deducing unknown words, and understanding graphic presentation (Ali, 2010).

According to Levine, Ferenz, \& Revez (2000), reading academic texts is an essential skill that second language learners need to master. Without proper reading skills, the students will not understand the text's information, evaluate it, or apply the ideas in real-life situations. 
Reading texts are usually followed by questions, which mostly become the vital part of reading objectives.

Unfortunately, there are some problems in teaching English textbooks, as some may not cover the higher levels of reading comprehension skills (Freahat \& Smadi, 2014). They will focus on reading skills in literal levels and a few in appreciation levels, thus ignoring the higher reading skills level. The skills play a very influential role as they are meant to develop concepts, build background, clarify reasoning processes and even lead students to a higher level of thinking (Fitria, Syarif \& Refnaldi, 2014).

As the researchers aim to investigate the degree of practicing Intensive Reading skills, they conclude that the most common skills in Intensive reading are: skimming, scanning, understanding the author's use of language, locating and recalling information, finding main ideas, drawing conclusions, making generalizations, sequencing events, distinguishing fact from opinion, determining the author's purpose, relating the text to personal experience, developing awareness about synonyms and antonyms, distinguishing between cause and effect, drawing conclusions from the information given in the text, making predictions and finding meanings of new vocabulary in contexts.

\subsection{Literature Review}

Some studies have examined the Intensive Reading skills on reading comprehension based on some variables. As an example, Khazaal (2019) examined the impact of intensive reading strategy on English for specific purposes college students' developing vocabulary. To achieve the aim of the study, 40 College students (20 students in the experimental group and the same number in the control group) were randomly chosen from the college of political sciences at A-Nahrain University in Iraq during the academic year 2017-2018. A pre-post-test of 50 items was administered for both groups. The control group was treated by the traditional way of teaching vocabulary, while the experimental group was treated by using an intensive reading strategy for about ten weeks. Based on the findings, it was found that the new strategy has a positive impact on students' mastering vocabulary that was proven from the improvement of students' mean scores from pretest to posttest.

On the other hand, Miftah (2013) examined the developed Intensive-Extensive Reading Strategy (IERS) to improve the students' reading comprehension. The participants of the study consisted of 32 students of the second semester of English Education Study Program of STAIN Palangka Raya in the 2010/2011 academic year. The data were gained from reading comprehension test, observation, field notes and questionnaire. The results revealed that during the implementation of IERS, it was improved the percentage of the students achieving the score greater than or equal to $\mathrm{C}(60-69)$, and the percentage of their involvement in the reading activities. Consequently, the implementation of Intensive-Extensive Reading Strategy can improve the students' reading comprehension but it should follow the appropriate procedures of the implementation of IERS.

To compare the effectiveness of intensive and extensive reading comprehension strategies, Erfanpour (2013) examined the effect of intensive and extensive reading strategies on EFL learners' reading comprehension. To achieve this goal, $70 \mathrm{EFL}$ male students were selected randomly from two different high schools in Shiraz (the participants were assigned to two equal groups: 35 students in the intensive group and 35 students in the extensive group). The extensive group was helped by their teacher to become familiar with various books other than their textbook for ten weeks. In contrast, the intensive group studied their textbook, plus ten texts. To collect the data, both groups took pre and post-reading exams, and an interview was conducted with five students in each group about the effect of these two strategies on reading comprehension. The results from the interview and reading exam indicated that these two strategies, in particular, extensive reading, had a positive effect on EFL learner's reading comprehension.

Also, Hong-Nam and Leavell (2006) investigated the Language learning strategy use of ESL students in an intensive English learning context. The participants of the study were 55 ESL students enrolled in a college Intensive English Program (IEP). The study revealed a positive relationship between strategy use and English proficiency, revealing that students in the intermediate level reported more use of learning strategies than the beginning and advanced levels. The study also found that the students preferred to use metacognitive strategies most, whereas they showed the least effective and memory strategies, and females tended to use affective and social strategies more frequently than males.

Salataci and Akyel (2002) conducted a descriptive study investigating the possible effects of intensive reading instruction on reading in Turkish and English. The participants consisted of 8 Turkish students enrolled in a pre-intermediate level class of a one-year intensive English course at a Turkish technical university. The researchers collected data from think-aloud protocols, observation, a background questionnaire, a semi-structured interview, and the reading component of the Preliminary English Test (PET). The results indicated that the Intensive Reading strategy had a positive effect on comprehension reading in English.

Also, Bell (2001) carried out a study to compare the effectiveness of Intensive and Extensive reading speed and reading comprehension. The participants consisted of 26 students at the British Council English Language Centre in Sana'a, Yemen. They were divided into two groups (14 received an extensive reading program, and 12 received an intensive program). The results of the reading 
comprehension test showed that the students in the Extensive Reading group received more significant results than students in the Intensive Reading group.

In light of previous studies, it can be concluded that the Intensive Strategy still requires further research, especially in the context of English as a foreign language, and the current study aims to explore the problem more deeply by addressing several variables such as the attitudes of learners from reading comprehension, and gender as one of the factors affecting student reading comprehension. The researchers generally benefited from these studies in determining the study's importance and the need for it and developing the study instrument. This study distinguishes from other previous studies that most studies focused on the Intensive, while the current study focused on teacher practice of Intensive Reading Skills.

\subsection{Problem and Questions of the Study}

The main aim of reading comprehension in the English Language, as the Ministry of Education (MoE) (2006) introduced, is to help students to read and comprehend English in different contents.

Miftah (2013) claimed that despite the importance of reading, many English teachers are wrestling with the issue of why students lack the skills necessary to comprehend English texts. He added that the majority of students still have a low ability to comprehend English texts. Those problems are caused by several factors, such as; the strategy the teacher employed was more teacher-centered and conventional. Besides, the teacher seldom applied various activities in teaching reading for his/her students to increase the students' motivation to read.

Teachers mostly claim that students suffer from a lack of reading comprehension in the English language. Poor performance in reading persists among secondary school students, and students who perform poorly in reading usually develop negative attitudes toward reading, and invariably the development of undesirable reading habits (Tunde-Awe, 2014).

The problem of this study lies in trying to detect the degrees of practicing Intensive Reading comprehension skills for teachers of English in the eleventh grade, by answering the following questions:

- What are the degrees of practicing the skills of Intensive English Reading by eleventh-grade students in the Directorate of Education for IrbidKasbah District from their points of view?

- Are there any statistically significant differences at $(\alpha$ $=0.05)$ in the degree of practicing the skills of Intensive English Reading by eleventh-grade students in the Directorate of Education in Irbid Kasbah District from their points of view, due to their gender (male, female)?

\subsection{Purpose Statement}

The purpose of this study was to examine the degrees of practicing the Intensive English Reading skills by eleventh-grade Students in the Directorate of Education for IrbidKasbah District from their points of view.

\subsection{Significance of the Study}

Intensive reading skills are necessary, and they provide new language elements for students if they are implemented comprehensively with all skills. This study's significance identified the degree of implementing the Intensive Reading skills to learn reading comprehension for the eleventh grade in the Directorate of Education in Irbid Kasbah District. Also, this study may hopefully contribute to the teaching and learning of English in the Jordanian context by providing the EFL teachers and curriculum designers with researched data on practicing Intensive Reading comprehension skills.

\subsection{Limitations of the Study}

This study was limited to the eleventh grade English students from the Directorate of Education in Irbid Kasbah District in Jordan during the first semester of the academic year (2020-2021).

\subsection{Definition of Terms}

The following terms are operationally defined to clarify usage in the current study:

Reading comprehension: According to Millrood (2011), reading comprehension is "a visual and cognitive process to extract meaning from writing by understanding the written text processing information and relating it to existing experience" (2011, p. 117). In this regard, the researchers define reading comprehension as a process that involves the reader's interaction, the text, and the context. It is the ability to understand what is being read. It is an interactive technique in which the reader uses different skills to interact with the text and employ his/her experience and previous knowledge to get the intended meaning.

Intensive reading: According to Koay (2015), Intensive reading refers to the way of reading through every word of a text from beginning to end very thoroughly and deeply. In this regard, the researcher defines Intensive reading to read short texts thoroughly and with clear goals. Intensive reading is a classroom activity, aims to develop the students' ability on how to understand detailed information. It is carried out under the supervision of a teacher primarily concerned with texts, which contain new words and idioms. It involves focusing on question-and-answer teaching methods and explaining presentations and representation to communicate meanings of words. It also describes the vocabulary and 
rules to be taught and the order in which it should be submitted.

Intensive Reading skills: they are the most common skills in Intensive reading: skimming, scanning, understanding the author's use of language, locating and recalling information, finding main ideas, drawing conclusions, making generalizations, sequencing events, distinguishing fact from opinion, determining the author's purpose, relating the text to personal experience, developing awareness about synonyms and antonyms, distinguishing between cause and effect, drawing conclusions from the information given in the text, making predictions and finding meanings of new vocabulary in contexts

Eleventh Grade English Students: students who learn the English Language for eleventh grade from the Directorate of Education in Irbid Kasbah District in the academic year (2020/2021).

\section{Method and Procedures}

\subsection{The Design of the Study}

The researchers used the descriptive-analytical method to analyse the opinions of Students about their practices Intensive Reading Comprehension Skills, and therefore this method was used in answering the questions of this research. There is one variable of this study, which was a student's gender (Male, Female).

\subsection{Population and Participants of the Study}

The study population was 1052 students from 19 schools in the Directorate of Education in Irbid Kasbah District, and researchers randomly selected $10 \%$ from different schools. Participants of the study were randomly selected male and female students for the eleventh grade of the Directorate of Education in Irbid Kasbah District for the academic year (2020/2021), and the number 101 male and female students, distributed as shown in Table 1.

Table 1. The participants of the study variable

\begin{tabular}{|c|c|}
\hline Gender & Total \\
\hline Male & $\mathbf{4 3}$ \\
\hline Female & $\mathbf{5 8}$ \\
\hline Total & $\mathbf{1 0 1}$ \\
\hline
\end{tabular}

\subsection{The Instrument of the Study, Validity, and Reliability}

To fulfil the aim of the study, the researchers developed a questionnaire. This instrument measured the degree of practicing the Intensive Reading comprehension skills of students in the Directorate of Education in Irbid Kasbah District from their points of view. The final draft of the questionnaire consisted of 18 items. Each one identifies one reading skill.

To ensure the validity of the students' questionnaire, it was presented to a jury of five EFL Professors from the curriculum and instruction department at Yarmouk University and five EFL supervisors for their recommendations regarding the clearness of the items and their suitability to the sample of the study. Their comments were taken into consideration in preparing the final draft of the questionnaire.

Cronbach's alpha was used to administer the reliability of the students' questionnaire. By data analysis, the results showed that the measured reliability by 'Cronbach Alpha' formula was (0.88), which is considered acceptable for conducting the questionnaire.

\subsection{Statistical Analysis}

Quantitative data analysis methods have been used. The questionnaire data were processed and analysed through the Statistical Package for the Social Sciences (SPSS), the researchers extracted the means, standard deviations, and ranks for each item, and the researchers also used a T-test. To interpret the results, the researchers adopted the following degrees to measure the practice: $(1-2.33=$ low, $2.34-3.65=$ moderate, $3.66-5=$ High)

\section{Results of the Study}

\subsection{Results Related to the First Question}

What are the degrees of practicing the skills of Intensive Reading by eleventh-grade Students in the Directorate of Education in Irbid Kasbah District from their points of view?

To answer this question, the researchers extracted means, standard deviations, and ranks for the degrees of Intensive English Reading skills which students practice from their points of view, as in Table 2 .

The results indicated that the total degree of practicing Intensive Reading skills of eleventh-grade students' points of view from the Directorate of Education in Irbid Kasbah District was low in general. As shown in Table 2, the mean scores for the total degree of practicing Intensive Reading skills were (2.32) with a standard deviation of (1.34). The results also indicated that only one Intensive Reading skill has a high degree of practice. This skill is scanning the text to extract the details with a mean of (3.71) and standard deviation (1.49). 

in the Directorate of Education in Irbid Kasbah District from Their Points of View

Table 2. Ranks, means, and standard deviations for the of the practicing Intensive Reading skills degrees

\begin{tabular}{|c|c|l|c|c|c|}
\hline Rank & No. & Reading Comprehension Skill & Mean & SD & Degree of practicing \\
\hline 1 & 3 & I scan the text to extract the details. & 3.71 & 1.49 & High \\
\hline 2 & 16 & I read the text to extract the sequencing events. & 3.40 & 1.20 & moderate \\
\hline 3 & 4 & I skim the text to extract the general idea. & 3.03 & 1.28 & moderate \\
\hline 4 & 7 & I combine ideas to summarize the text. & 2.99 & 1.21 & moderate \\
\hline 5 & 18 & I develop my awareness of synonyms and antonyms. & 2.87 & 1.05 & moderate \\
\hline 6 & 1 & I determine the author's purpose in the text. & 2.68 & 1.30 & moderate \\
\hline 7 & 10 & I conclude the information given in the text, & 2.44 & 1.49 & moderate \\
\hline 8 & 2 & I read the text to find the main idea of each paragraph. & 2.26 & 1.28 & low \\
\hline 9 & 9 & I distinguish fact from opinion from the text. & 2.15 & 1.08 & low \\
\hline 10 & 14 & I infer the motives of characters and themes. & 2.09 & 1.38 & low \\
\hline 11 & 11 & I distinguish between cause and effect from the text. & 1.92 & 0.88 & low \\
\hline 12 & 15 & I read the text to make predictions about the events. & 1.88 & 1.05 & low \\
\hline 13 & 12 & I make generalizations after finishing the reading text, & 1.87 & 1.21 & low \\
\hline 14 & 5 & I read the text to understand the author's use of language. & 1.85 & 1.18 & low \\
\hline 15 & 17 & I relate the text to personal experience. & 1.84 & 0.99 & low \\
\hline 16 & 13 & I interpret and evaluate the information from the text & 1.82 & 0.95 & low \\
\hline 17 & 6 & I find meanings of new vocabulary in contexts. & 1.52 & 1.18 & low \\
\hline 18 & 8 & I locate and recall the information from the text. & 1.48 & 1.03 & low \\
\hline
\end{tabular}

Also, Table 2 indicated that six Intensive Reading skills have moderate degrees of practicing, which are (1) read the text to extract the sequencing events with a mean of (3.40) and standard deviation of (1.20); (2) skim the text to extract the general idea with mean of (3.03) and standard deviation of (1.28); (3) combine ideas to summarize the text with mean of (2.99) and standard deviation of (1.21); (4) develop my awareness about synonyms and antonyms with mean of (2.87) and standard deviation of (1.05); (5) determine the author's purpose from the text with mean of (2.68) and standard deviation of (1.30); conclude the information given in the text with mean of (2.44) and standard deviation of (1.05);

Thus, in answering this question, the results demonstrated that the total degree of practicing Intensive Reading skills was low, one skill has a high degree, six skills have moderate degrees, and eleven skills have low degrees from students' points of view in the Directorate of Education in Irbid Kasbah District.

\subsection{Results Related to the Second Question}

Are there any statistically significant differences at $(\alpha=$ 0.05 ) in the degree of practicing the skills of Intensive Reading by eleventh-grade students in the Directorate of Education in Irbid Kasbah District from their points of view, due to their gender (male, female)?

Table 3. The T-test between the Males and Females on their degrees of practicing Intensive Reading skills

\begin{tabular}{|c|c|c|c|c|c|c|}
\hline Group & $\mathrm{N}$ & Mean & $\mathrm{SD}$ & t-value & DF & Sig.* \\
\hline Male & 43 & 2.19 & 0.60 & \multirow{2}{*}{1.189} & \multirow{2}{*}{99} & \multirow{2}{*}{0.072} \\
\hline Female & 58 & 2.42 & 0.68 & & & \\
\hline
\end{tabular}

* Significant $=0.05$

To answer this question, an independent t-test was conducted to examine the mean difference between the two male and female groups on degrees of practicing Intensive Reading skills. Table 3 presents the means and standard deviations for the two male and female groups on degrees of practicing Intensive Reading skills from their points of view.

The results indicated that the mean for the male group was (2.19) with a standard deviation of (1.43), whereas the mean for the female group was (2.42) with a standard deviation of (1.27). Table 3 also shows that the $t$-value $(t$ $=0.268$; Sig. $=0.000)$, according to the results of the independent $\mathrm{t}$-test, indicate that there were statistically significant differences between the two means of the male and female groups in favour of the female in practicing the Intensive Reading skills degrees, that is, the two groups were not equal in their practicing the Intensive Reading skills from the teachers' points of view.

\section{Discussion of the Results and Recommendations}

\subsection{Discussion of the Results}

Due to the results of the statistical analysis of this study, it was found that the total degree of students' practicing Intensive Reading skills was low from their points of view: one skill has a high degree, six skills have moderate degrees, and eleven skills have low degrees from students' points of view in the Directorate of Education in Irbid Kasbah District.

This may be attributed to the fact that the instructions in the teacher's guide are not clear to teachers and that supervisory visits are so few that teachers are directed to focus on these practices. Otherwise, researchers believe 
that teachers' convictions for intensive reading are not up to the required level because teachers do not see it necessary after the great legacy that traditional teaching has left in government schools, especially for the time and effort required to rebuild concepts and standards, to increase the number of students in the classroom, the burden of lessons Weekly for the teacher, educational assignments and other related administrative tasks.

Alhabahba, Pandian \& Mahfoodh (2016) claimed that Jordanian students face difficulties in reading comprehension in learning the English language. Moreover, Tamsi, Zuhri \& Kurniasih (2013) found out that the teacher was not entirely successful in implementing Intensive Reading strategies in teaching reading text. Researchers conclude that the problems of teaching English comprehension reading in public secondary schools in Jordan already exist in large numbers among students, teachers, and English language curricula, thus forming a gap in learning and teaching reading in the English language.

The inadequacy of English language skills has been reported as one of the problems of English language education in Jordan (Al-Khatib, 2008). This may be attributed to the traditional methods of teaching English in Jordanian public schools that ignore teaching the culture of the English language, the teachers 'lack of knowledge of modern methods of learning reading in the English language that negatively affect students' learning, and finally the lack of suitable topics related to reading textbooks in the English curriculum which affects students' attitudes toward reading. This is in line with what Alzu'bi (2014) found that many students in Jordan gain little information from reading English material because they read without any special strategies for remembering new words.

Also, the current study results indicated that there were significant differences between male and female students in the degree of practicing the skills of Intensive Reading in favor of the female. This finding was somewhat consistent with results from some studies (such as Hong-Nam \& Leavell, 2006; Owodunni, 2018) that found that males are less interested than females in reading. Gender differences are often cited as an explanation for differences in reading preference between boys and girls. This result is because girls enjoy their English lessons more, feel less tired and less anxious to make mistakes, and learn English because they enjoy hearing or speaking it more than boys do and put in more effort. While girls generally like to read narrative fiction more likely to be accustomed to reading strategies such as scanning, re-reading, and discussing the text, boys typically enjoy a wider variety of genres covering a broader range of topics. (Canadian Council on Learning, 2009).
The researchers also attribute significant differences between male and female students in the degree of practicing the skills of Intensive Reading to the motivation toward reading. Student motivation guides their reading activity, determining the amount of input they are exposed to, the level of interaction with the content, and the quality of the response to the text (Khazaal, 2019). Differences in motivation towards reading between male and female students have been observed in several studies. Some studies have found that girls enjoy reading more than boys (Merisuo-Storm, 2006; Sullivan, 2004; Sadowski, 2010). Male students prefer texts that have a purpose: obtaining information, making things, and helping others. Likewise, male students do not like reading aloud, and even when they are fluent in reading, they feel embarrassed to do so, which may indicate a decrease in their motivation (Wilhelm, 2000). However, if Jordanian teachers want to enhance the motivation to learn to read in the language in boys, it is more useful to know the factors that contribute to motivating children to learn the language.

\subsection{Study Recommendations}

In light of the results of the current study, the following recommendations were made:

- In conducting the teaching-learning process, the English teacher should enrich his/her teaching with various activities and media.

- The teacher also should maintain the progress of the students in Intensive Reading and encourage them to read English texts more.

- The teacher should balance the teaching-learning activities to achieve the students' competencies in mastering the language's four skills.

- The school should provide more facilities that support the students in learning the English language, such as a language laboratory, English magazines, and internet connection.

- Design training programs for teachers in the secondary stage in public schools during the service, to include training needs related to Intensive Reading skills.

- Encouraging teachers during service to participate in and implement training programs by providing material and moral incentives, especially those who are more experienced.

- Holding specialized training workshops by the Ministry, educational departments, and educational supervision departments on Intensive Reading skills and how to apply them in the classroom.

- Conducting more studies on Intensive Reading skills for various variables. 


\section{Appendix (1)}

\section{Questionnaire the practicing of Intensive Reading Comprehension Skills}

Dear Student,

This questionnaire aims to measure the practicing of Intensive Reading Comprehension Skills for first Secondary Students from their points of view.

This questionnaire consists of 18 paragraphs. Each one identifies one reading skill, and you are required to read each paragraph and indicate the degree of its applicability in your class, from your points of view by placing a sign $(\sqrt{ })$ in the appropriate evaluation degree, from the following five degrees: (5) always, (4) often, (3)sometimes, (2)rarely, (1) never.

Note that the results of the questionnaire will only be used for scientific research.

General Information

Gender

$\square$ Male

$\square$ Female

Questionnaire of practicing the Intensive Reading Comprehension Skills

\begin{tabular}{|c|c|c|c|c|c|c|}
\hline & & \multicolumn{5}{|c|}{ Degree } \\
\hline & & always & often & sometimes & rarely & never \\
\hline No. & Reading Comprehension Skill & 5 & 4 & 3 & 2 & 1 \\
\hline 1 & I determine the author's purpose in the text. & & & & & \\
\hline 2 & I read the text to find the main idea of each paragraph. & & & & & \\
\hline 3 & I scan the text to extract the details. & & & & & \\
\hline 4 & I skim the text to extract the general idea. & & & & & \\
\hline 5 & I read the text to understand the author's use of language. & & & & & \\
\hline 6 & I find meanings of new vocabulary in contexts. & & & & & \\
\hline 7 & I combine ideas to summarize the text. & & & & & \\
\hline 8 & I locate and recall the information from the text. & & & & & \\
\hline 9 & I distinguish fact from opinion from the text. & & & & & \\
\hline 10 & I conclude the information given in the text, & & & & & \\
\hline 11 & I distinguish between cause and effect from the text. & & & & & \\
\hline 12 & I make generalizations after finishing the reading text, & & & & & \\
\hline 13 & I interpret and evaluate the information from the text & & & & & \\
\hline 14 & I infer the motives of characters and themes. & & & & & \\
\hline 15 & I read the text to make predictions about the events. & & & & & \\
\hline 16 & I read the text to extract the sequencing events. & & & & & \\
\hline 17 & I relate the text to personal experience. & & & & & \\
\hline 18 & I develop my awareness about synonyms and antonyms. & & & & & \\
\hline
\end{tabular}




\section{REFERENCES}

[1] Abraham, Paul (2002). Skilled reading: Top-down, bottom-up. Available at: www.sabes.org/resoures/fieldnotes /vollo1 fn102.

[2] Alderson, J. Charles (2015). Reading Assessing. New York: Cambridge University Press. 01(I): 1-20

[3] Al-Drees, M. (2008). Teaching Reading Skills. Imam Muhammad bin Saud Islamic University. Kingdom of Saudi Arabia.

[4] Alhabahb, M., Madallh; Pandian, Ambigapathy and Mahfoodh, O., H., Ali (2016). Curriculum \& Teaching Studies Review Article. English language education in Jordan: Cogent Education Journal, 13(3): 1-14. Available at: http://eprints.usm.my/38963/1/English_language_education in_Jordan.pdf

[5] Alhabahba, M., M.; Pandian, A., and Mahfoodh, O., (2016). English language education in Jordan: Some recent trends and challenges. Cogent Education 3: 1-14. http://dx.doi.org/10.1080/2331186X.2016.1156809

[6] Ali, N. (2010). An Evaluation of the Reading Texts \& Exercises in $S B$ \& WB of English for Palestine-Grade 9. Master's Thesis. The Islamic University of Gaza, Palestine.

[7] Al-Khatib, M. A. (2008). Innovative second and foreign language education in the Middle East and North Africa. In N. V. Deusen-Scholl \& N. H. Hornberger (Eds.), Encyclopedia of Language and Education, 2nd ed., (4): 227 237.

[8] Alpatkein, C. (2006). Cultural familiarity in inferential: a literal comprehension in language 2 reading. System, 34 (4): 494- 508.

[9] Al-Qudah, M., Al-Khataybeh, M., \& Mohaidat, M. (2002). Reading Comprehension: Influence of Brainstorming. $A$ bath Al-Yarmouk, 18 (3B): 109-120.

[10] Alzu'bi, M. A. (2014). The Effects of an Extensive Reading Program on Improving English as Foreign Language Proficiency in University Level. Education in English Language Teaching. 7(1): 28-35.

[11] Arinawati, Arinawati (2012) The Use of Video to Improve Students' Reading Comprehension on Advertisement Text ( $a$ Classroom Action Research with the Eighth Grade Students' of MTs NU Al-Hikmah Mijen Semarang in the Academic Year of (2011/2012). Undergraduate (S1) thesis, IAIN Walisongo.

[12] Asmawati, A., (2015). The Effectiveness of Skimming-Scanning Strategy in Improving Students' Reading Comprehension at the Second Grade of Smk Darussalam Makassar. ETERNAL (English, Teaching, Learning, and Research Journal) 1(1): 69-83. Available at: http://journal.uinalauddin.ac.id/index.php/Eternal/article/vie $\mathrm{w} / 2409$

[13] Attaprechakul, D. (2013). Inference Strategies to Improve Reading Comprehension of Challenging Texts. English Language Teaching, 6(3): 82- 101.

[14] Bell, T. (2001). Extensive reading: speed and comprehension. The Reading Matrix, 1(1): 1-13. Available at: http://www.readingmatrix.com/articles/bell/index.html

[15] Bernhardt, E. B. (2010). Understanding advanced second-language reading. Routledge.

[16] Cahyono, B. Y, and Widiawati. (2006). The Teaching of EFL Reading in the Indonesian Context: The State of the Art. TEFLON Journal: A Publication on the Teaching and Learning of English, 17(1): 36-58. Available at: http://www.teflin.org/journal/index.php/teflin/article/viewfi le/186/90.

[17] Canadian Council on Learning (2008). Why Boys don't like to read; Gender differences in reading achievement, February $18^{\text {th }}$.

[18] Clarke, P., Truelove, E., Hulme, C., \& Snowling, M. (2013). Developing reading comprehension. Hoboken: Wiley.

[19] Erfanpour, Mohammad (2013). The Effect of Intensive and Extensive Reading Strategies on Reading Comprehension: A Case of Iranian High School Students. English for Specific Purposes World, 41(14): 1682-3257

[20] Fitria, E., Syarif, H., and Refnaldi. (2014). An Analysis Of Reading Comprehension Questions In Textbooks 'English Texts In Use And Look Ahead' For Senior High School Grade X”. Journal English Language Teaching, 2(2): 1-15.

[21] Fountas, I., \& Pinnell, G. S. (2001). Guiding Readers and Writers: Teaching reading comprehension, genre, and content literacy. Portsmouth, NH: Heinemann.

[22] Freahat, N. M., \& Smadi, O. M. (2014). Lower-order and higher-order reading questions in secondary and university level EFL textbooks in Jordan. Theory and Practice in Language Studies, 4(9): 1804-1813.

[23] Gorsuch, G. (2012). Fluency instruction in reading in a second or foreign language. Fluency Instruction: Research-Based Best Practices, 2(16): 1539-0578.

[24] Grabe, W. (2010). Fluency in reading-thirty-five years later. Reading in a foreign language, 22(1): 71-83.

[25] Hamdan, J. (1991). Reading: A three-phase Approach. UNRWA HQ. Amman. Jordan.

[26] Hoeh, E. (2015). Mapping a path to understanding: Supporting the comprehension of narrative text for students with learning disabilities and typically developing peers. (Doctoral Dissertation). University at Buffalo, State University of New York. Available at: http://www.proquest.com

[27] Hong-Nam K, Leavell AG. (2006). A Comparative study of language learning strategy use in an EFL context: Monolingual Korean and bilingual Korean-Chinese University students. Asia Pacific Education Review, 8 (1): 71-88.

[28] Huang, H. C. (2013). E-reading and e-discussion: EFL learners' perceptions of an e-book reading program. Computer Assisted Language Learning, 26 (3): 258-281.

[29] Kendeou, P., McMaster, K. L., \& Christ, T. J. (2016). Reading comprehension: Core components and processes. Policy Insights from the Behavioral and Brain Sciences, 3 (1): 62-69. Available at: https://doi.org/10.1177/237273221 5624707 
[30] Khazaal, Edhah Numan (2019). Impact of Intensive Reading Strategy on English for Specific Purposes College Students' in Developing Vocabulary. Arab World English Journal $(A W E J), \quad 2 \quad(10)$ : 181-195: Available at https://dx.doi.org/10.24093/awej/vol10no2.15

[31] Koay, J.(2015). What is Intensive Reading? Independent Researcher and a Research \& Development Consultant at EduMaxi. Victoria University of Wellington, School of Linguistics and Applied Language,

[32] Levine, A., Ferenz, O., \& Revez, T. (2000). EFL academic reading and modern technology: How can we turn our students into independent critical readers? TESL-EJ, 4(4): 1072-4303. Available at: http://www.tesl-ej.org/wordpress/ past-issues/volume4/ej16/ej16a 1/.

[33] MacLeod, Maija. (2013). Types of Reading Article (Online). Available at: https://slllc.ucalgary.ca/Brian/611/readingtype .html,

[34] Mayer, R. (2003). Learning and Instruction Upper Saddle Kiver. New Jersey's Pearson Education Inc.

[35] McDonough, J., and Shaw, S. (1993). Materials and Methods in ELT, a teacher's guide. Oxford: Blackwell.

[36] Merisuo-Storm, T. (2006). Girls and boys like to read and write different texts. Scandinavian Journal of Educational Research, 50 (2): 111-125

[37] Miftah M. Zaini (2013). Implementation of Intensive-Extensive Reading Strategy to Improve Reading Comprehension. Journal on English as a Foreign Language, $1(3): 21-29$

[38] Millrood, R. (2011). Modular course in ELT methodology. Moscow. Drofa.

[39] MoE (Ministry of Education) (2006). General Guidelines for English Subject and General and Specific Outcomes for the English Language Curriculum. Amman: Jordan.

[40] Murphy, V. A. (2015). A systematic review of intervention research examining English language and literacy development in children with English as an additional language (EAL). Available at: https://educationendowmentf oundation.org.uk/uploads/pdf/EAL Systematic review1.pd f

[41] Nuttall, Christine (1986). Teaching Reading Skills in a Foreign Language. London: Heinemann Educational Books.

[42] Owodunni M. A. (2018). Effects of Extensive Reading Strategy on Students Achievement in Reading Comprehension. Lonaka JoLT 9 (1): 172-181.
[43] Paran, A. (2003). Intensive Reading. English. Teaching Professional, 28: 40-48.

[44] Pollard-Durodola, S. D., Gonzalez, J. E., Simmons, D. C., Kwok, O., Taylor, A. B., Davis, M. J., \& Simmons, L. (2011). The effects of an intensive shared book-reading intervention for preschool children at risk for vocabulary delay. Exceptional Children, 77(2): 161-183.

[45] Popescu, A. V. (2012). Vocabulary and Reading Comprehension. Annales Universitatis Apulensis. Series Philologica, 13(2): 531-540.

[46] Rabel, N. (2005). Reading to Children is Essential. Available at: http://ohioline.osu.edu/hygfact/5000/5287.htm 1

[47] Richards, J. S., and Renandya, W. A. (2002). Methodology in Language Teaching: an Anthology of Current Practice. New York: Cambridge University Press.

[48] Sadowski, M. (2010). Putting the "boy crisis" in context. Education Digest: Essentil Readings Condensed for Quick review, 76 (3), 10-13.

[49] Salataci R, Akyel A. 2002. Possible effects of strategy instruction on $\mathrm{L} 1$ and $\mathrm{L} 2$ reading. Reading in a foreign language, 14 (1): 234- 255.

[50] Sullivan, M. (2004). Why Johnny won't read. School Library Journal, 50 (8), 36-39.

[51] Tamsi, Resya K., Zuhri, F., \& Kurniasih, E. 2013. The Implementation of Skimming and Scanning Strategies in Teaching Reading Narrative Text to the Tenth Grade Students of SMAN 21 SURABAYA. Ejournal Unesa, 1(1):1-7. Available at:http://ejournal.unesa.ac.id/index.php/ retain/article/view/2618/bacaartike

[52] Vaughn, S. (2012). Effects of intensive reading intervention for eighth-grade students with persistently inadequate response to intervention. Journal of Learning Disabilities, 45(6): 515-525.

[53] Wong, B. (2011). Learning about learning disabilities. Burlington: Elsevier Science. Available at: https://ebookcen tral.proquest.com/lib/wmichlibebooks/detail.action?docID= 294624

[54] Wright M, Brown P (2006). Reading in a modern foreign language: exploring the potential benefits of reading strategy instruction. Language Learning Journal, 33: 22-33.

[55] Yang, W. Dai, w. Gao, L. (2012) Intensive Reading and necessity to Integrate Learning Strategies. English Language and Literature. 2(1): 55-63. 